\title{
Sensory Analysis in the Garment and Textile Industry
}

\author{
Rosimeiri Naomi Nagamatsư ${ }^{1,2}$, Maria José Araújo Marques de Abreu²* and Cosmo Damião Santiago ${ }^{1}$ \\ ${ }^{1}$ Federal Technology, University of Paraná, Brasil
}

${ }^{2} 2$ C2T-Center for Textile Science and Technology, Minho University, Portugal

Submission: November 12, 2019; Published: February 25, 2020

*Corresponding author: Maria José Araújo Marques de Abreu, 2C2T- Center for Textile Science and Technology, Minho University, Azurém, Portugal

Keywords: Sensory analysis, Textile industry, Garment, Tactile sensory comfort, Material, Psychological, Tactile feeling, Lexicons, Tissues, Statistical analysis, Cosmetics, Food products, Specific product, Visual sensory evaluation, Non-food sectors

\section{Mini Review}

As a strategy to improve product marketing, sensory analysis has increasingly been exploited by non-food sectors to evaluate different products. Textile sensory analysis has been the focus of studies to measure and compare the quality in different types of textile products in view of user comfort. Tactile sensory comfort in textiles is the result of the amount of tension generated in the material in contact with the skin. Thus, it has a strong relationship between tactile function and mechanical properties of fabrics. The tactile properties of fabric sensory comfort were standardized through descriptive and psychophysical sensory analysis techniques from the 1990's [1]. This method has been adapted from international standards developed for the evaluation of food and cosmetics. Commonly, sensory assessment uses sense perception (vision, smell, hearing, taste, and touch) to assess attributes of food products. This sensory evaluation in textiles is the result of descriptive psychological and physiological responses of individuals, where the sensations, when a material is touched, are quantified, and the human hand is the only instrument applied. In textiles, sensory analysis has been mainly investigated by tactile perception [2-9]. All of these sensory comfort investigators evaluated textile samples (twodimensional structures) with certain textile finishing or coming from a specific product and / or specific characteristics, however, they did not explore the tactile sensory evaluation of a textile product in its three-dimensional form, i.e., the product in its final form.

It is difficult to define comfort and to meet the desired level of satisfaction and specific performance, it is necessary to define the intended end-use terms for clothing [10], that is, to know which comfort attributes are desired by the consumer. Therefore, sensory analysis is a significant new tool for textile materials in general where tactile feeling is of paramount importance to the consumer. Sensory analysis methodologies use descriptive research to characterize the attributes of different types of products and involve qualitative and quantitative analysis of sensory perceptions. For the sensory analysis some steps are necessary: preparation of the work environment [11]; selection and training of volunteers [12] and development of their own lexicon [13]. Finally, after the evaluators have gone through the training sessions, it is possible to conduct the tests for the evaluation of the samples, following the methodology of quantitative descriptive sensory analysis, evaluating, comparing and discriminating the product as a whole or by its individual characteristics [14]. It is also possible, through statistical analysis, to determine if there are significant differences between the samples used. Philippe et al. (2004) [15] made the first investigations in France adapting the sensory analysis norms of the food sector, where they developed lexicons for the tactile sensory evaluation in tissues.

Nogueira (2011) [16] later compared Portuguese and French lexicons, and added to their studies visual sensory evaluation. Other studies of quantitative sensory analysis in textiles have been done by other researchers [1,4,6,17-22] however, only Portuguese research made a comparative study with two trained panels, one Portuguese and one French, thus validating the methodology. Nagamatsu et al. [23] used the same methodology 
employed by Philippe et al. [24] and Nogueira et al. [25] and developed a Brazilian lexicon for the selection and training of a sensory panel and later for the evaluation of textile samples. Brazilian lexicons were compared with those developed in France and Portugal, noting that seven attributes in common are the most mentioned among the panels: light and heavy; thick and thin; cold and warm; soft; plushy; elastic and the falling Nagamatsu et al. [9]. These attributes offer high subsidies for the assessment of textile tactile comfort, as well as to describe its tactile qualities, and can also be used as a strategy by the textile and garment industries to improve the process of developing and marketing their products worldwide.

\section{Acknowledgement}

This work is financed by FEDER funds through the Competitivity Factors Operational Program - COMPETE and by national funds through FCT - Foundation for Science and Technology within the scope of the project POCI-01-0145FEDER-007136.

\section{References}

1. Sztandera LM, Cardello AV, Winterhalter C, Schutz H (2013) Identification of the most significant comfort factors for textiles from processing mechanical, handfeel, fabric construction, and perceived tactile comfort data. Textile Research Journal 83(1): 4-43.

2. Philippe F, Abreu MJ, Schacher L, Adolphe DC, Silva MEC (2003) Influence of the sterilisation process on the tactile feeling of surgical gowns. Science And Technology 15(3/4): 268-275.

3. Guest S, Spence C (2003) What role does multisensory integration play in the visuotactile perception of texture? International Journal of Psychophysiology 50(1-2): 63-80.

4. Chollakup R, Sinoimeri A, Philippe F, Schacher L, Adolphe D (2004) Tactile sensory analysis applied to silk/cotton knitted fabrics. International Journal of Clothing Science and Technology 16(1/2):132140.

5. Li Y, Wang Z (2005) Thermal sensory engineering design of textile and apparel products. Elsevier Ergonomics Book Series, 3: 473-476.

6. Bacci L, Camilli F, Drago S, Magli M, Vagnoni E (2012) Sensory evaluation and instrumental measurements to determine tactile properties of wool fabrics. Textile Research Journal 82(14): 1430-1441.

7. Sabiri N, Leblond L, Villoutreix J, Lavergne M, Acétarin JD, et al. (2008) Touch study of polymer materials surfaces-description of raspiness by a correlation approach between sensorial analysis and physical measurements. Advanced Engineering Materials 10(4): 407-413.

8. Sabir E, Doba Kadem F (2016) Comfort and Performance Properties of Raised and Laminated Denim Fabrics. Fibres and Textiles in Eastern Europe 5(119): 88-94.

9. Nogueira C, Abreu MJ, Silva MEC, Schacher L, Adolphe D (2009) The role of the sensory analysis in the development of textile materials.
10. Fayala F, Alibi H, Jemni A, Zeng X (2015) A new hybrid artificial intelligence approach to predicting global thermal comfort of stretch knitted fabrics. Fibers and Polymers 16(6): 1417-1429.

11. ABNT (2015) ISO 8589-Análise sensorial - Guia geral para o projeto de ambientes de teste. Rio de Janeiro, Brasil.

12. ABNT (2016a) NBRISO11132_ Sensory analysis - Methodology-Guide to monitor the performance of a quantitative sensory panel. pp. 1-29.

13. ISO (1994) ISO-11035-Sensory analysis-Identification and selection of descriptors for establishing a sensory profile by a multidimensional approach. ( $\left.1^{\text {st }} \mathrm{edn}\right)$, pp. 1-26.

14. ABNT (2016b) NBRISO11132_Guia para monitorar o desempenho de um painel sensorial quantitativo.

15. Philippe F, Schacher L, Adolphe DC, Dacremont C (2004) Tactile feeling: Sensory analysis applied to textile goods. Textile Research Journal 74(12): 1066-1072.

16. Nogueira C (2011) Análise sensorial de produtos têxteis. Doctoral thesis in Textile Engineering.

17. Wong ASW, Li Y, Yeung PKW (2003) Performances of Artificial Intelligence Hybrid Models' in Prediction of Clothing Comfort from Fab.

18. Kweon SA, Lee EK, Choi JM (2004) A comparative study on the subjective fabric hand according to gender for winter sleepwear fabrics. Fibers and Polymers 5: 6-11.

19. Ryu HS, Eui Kyung Roh (2010) Preference and subjective evaluation of washed fabric hand using conjoint analysis. Textile Research Journal 80(20): 2167-2175.

20. Barker LR (2002) From fabric hand to thermal comfort the evolving role of objective measurements in explaining human comfort response to textiles. International Journal of Clothing Science and Technology 14(3/4): 181-200.

21. Strazdienė E, Ben Saïd S, Gutauskas M, Schacher L, Adolphe DC (2006) The evaluation of fabric treatment by Griff tester and sensory analysis. International Journal of Clothing Science and Technology 18(5): 326334.

22. Bertaux E, Derler S, Rossi RM, Xianyi Zeng, Koehl L, et al. (2010) Textile, Physiological, and Sensorial Parameters in Sock Comfort. Textile Research Journal 80(17): 1803-1810.

23. Nagamatsu RN, Abreu MJ, Santiago CD, Tama D (2018) Determination of total comfort of sport caps using wear trials. Fiber Society 2018 Spring Conference: Fibers and Textiles for Value Creation in Connected Industries.

24. Philippe F, Schacher L, Adolphe DC, Dacremont C (2003) The Sensory Panel Applied to Textile Goods-A New Marketing Tool. Journal of Fashion Marketing and Management 7(3): 235-248.

25. Nagamatsu RN, Abreu MJ, Santiago CD (2017) Tactile feeling of textile: a comparative study between textiles comfortable attributes of France , Portugal and Brazil. Fiber Society. 
(C) This work is licensed under Creative

CC Commons Attribution 4.0 Licens

DOI: 10.19080/CTFTTE.2020.06.555687
Your next submission with Juniper Publishers will reach you the below assets

- Quality Editorial service

- Swift Peer Review

- Reprints availability

- E-prints Service

- Manuscript Podcast for convenient understanding

- Global attainment for your research

- Manuscript accessibility in different formats

( Pdf, E-pub, Full Text, Audio)

- Unceasing customer service

Track the below URL for one-step submission https://juniperpublishers.com/online-submission.php 